\title{
Factors Responsible For Frequent Withdrawal of Girls from Schools and Their New Enthusiasm for Re-Joining Formal Education after Years of Break:
}

\author{
${ }^{1}$ Ummu Kaltumi Yakubu, ${ }^{2}$ Muhammad Babuga Binji, ${ }^{3}$ Abdullahi Muhammad \\ Sokoto \\ ${ }^{1}$ Federal Government College, Lagos, Nigeria, \\ ${ }^{2}$ Department of Mathematics, Shehu Shagari College of Education, Sokoto,Nigeria, \\ ${ }^{3}$ Department of Mathematics, Shehu Shagari College of Education, Sokoto,Nigeria
}

\begin{abstract}
Despite many calls from both the government and non governmental agencies, there was still low enrolment level of the female students, poor participation and their frequent withdrawal in schools in Sokoto state. This research was conducted to identify the reasons why they withdrew from schools and the motivating factor for their re-joining schools after a long break. The sample consisted of 300 students who were all females in categories of single, married, divorced and widows, selected randomly from Women Centre for Continuing Education, Sokoto. Fifty other respondents that consisted of teachers of the school, civil servants, NGO's and self employed people. A 24 item self designed questionnaire was administered to the respondents. The study found out that the establishment of the Women Centre for Continuing Education, and the conducive learning environment in the school helped motivate the re-joining of the school by the dropouts. Also that the students both single, married, divorced and widowed have almost the same views of re-joining the school. It was recommended that more of these schools should be established in all the local governments in the state. Also education should be made totally free for women, and more enlightenment campaigns on laws prohibiting withdrawal of females from school should be carried out by the government.
\end{abstract}

\section{Background to the Study}

\section{Introduction}

In spite of global efforts to bridge the gender gap in education, such as awareness campaigns on the need for women education, UNICEF's provision on the need to improve the education of the girl child etc. there is very little to show that much has been achieved. In fact, the statistics consistently released by UNESCO have continued to show a frightening increase in the number of illiterate women worldwide. From a global rate of $58 \%$ in 1970 and 63\% in 1980, the NESCO, cited by Dukku (1997) reported that between 1960 and 1985, the number of illiterate women grew by $86 \%$. Of a global total of 154 million, for the African continent, there was an almost 50 percent increase in the number of illiterate persons (from 68 million to 98 million). For the 25 years from 1960 to 1985, more than two thirds of these are females the 2001 human index report of the United Nations Development Programme (UNDP) fingers dwindling economic fortunes, general mismanagement by governments and inconsistent official government policies as factors responsible for this situation.

The natural question that readily comes to mind is; what has been responsible for this state of education? Many factors account for this imbalance, the most important one being parents attitude towards the education of girls and the sex stereotyping of girls in society. Though Islam, the predominant religion in Sokoto state favours and encourages education among males and females, it appears that the society has found a convenient way out by attempting to shut the door of education against women. On the whole, there is a general disdain for western education in the state, (Abdulrahman 1997).

According Ibrahim (2008), debilitating poverty and dwindling means of income by most parents is not helping matters rather than send their daughters to school, most poor parents would rather turn the blind eye or even positively encourage their daughters to take to hawking as a means of augmenting the income of the family. Another angle to the issue of poverty is that unwilling parents would quickly point to the growing army of unemployed graduates as an excuse to keep females out of school.. Despite the huge financial resources spent on education by the state government, the truth of the matter is that there are several other hidden, yet prohibitive costs of schooling. Abdulrahman (1997) lists some of these hidden costs to include; cost of uniforms, examination, fees, cost of other materials either not supplied by, or in addition to what government supplied and the cost on parents of supporting their wards while schooling.

As a result of increasing government commitment, greater awareness has been created nationwide on girls' education especially with the launch and ledge by the federal ministry of education to mainstream girls' education into the EFA plan. Some states in Northern Nigeria have already promulgated edicts to support the 
promotion of education. For example Kano state has prohibited the collection of all forms of fees in all girls' secondary schools; Similarly Gombe state promulgated an edict against withdrawal of girls from schools, while Niger, Bauch, and Yobe states have removed financial disincentives affecting girls enrolment in secondary schools. Those out as a result of early marriage and or teenage pregnancy are encouraged to return to school as the case with the women centre for continuing education in Sokoto state. (Dabo, 2000).

The school also allows the students to attend with their children. These are opportunities which years back women had not got, to rejoin formal school at the time appropriate and conducive to them. Most of the married women when interviewed said they were in the school with the permission and consent of their husbands. In Sokoto the much vaunted traditional cultural and religious factors, hitherto fingered as the main culprits have teamed with dwindling economic fortunes of most families to further worsen the situation of poor enrollment of women in schools.

\section{Statement of the Problem}

This research intends to find out government policy on women education and actual situation on the ground with particular reference to this centre, (women centre for continuing education). In the 1980's the state government, in pandering to the clamour from a section of the society established more single sex schools. This programme virtually ended co educational institutions in the state. In taking that decision, Dikko (2001) said government was swayed by the argument that co educational institutions negate certain Islamic injunctions, which discouraged mixing of both sexes in the same enclosures. It was hoped that this would encourage parents to release their daughters to school.

Although there has been an increase in students' enrolment, comparatively speaking, the figures represent a decline in the number of girls in school. This means there is a more fundamental problem facing women education than government anticipated, since the issue has become even more disturbing, considering the fact that most women do not participate in any visible economic production, it has become necessary to find workable ways round the problem

\section{Objectives of the Study}

1. To find out the possible reasons for frequent withdrawal of female students from their schools in Sokoto State.

2. To find out the possible reason for the new enthusiasm on the part of women, single, married, divorced and widows for rejoining formal education after many years of break.

3. To find out whether there could be different views among the single women, married, divorced and widow for rejoining formal education after years of break.

\section{Research Questions}

1. What are the possible reasons for frequent withdrawal of female students from their schools in Sokoto State?

2. What are the possible reasons for the new enthusiasm on the part of women, single, married, divorced and widows for education?

3. Could there be different views among single women, married, divorced and widows for rejoining formal education after years of break?

\section{Significance of the Study}

The findings of this study are expected to be of immense benefit to the government, educational policy makers, parents and husbands towards effecting a change of societal attitude with regard to female education. Parents, husbands and women, the victims of this societal attitude would benefit immensely from the findings of the study.

\section{Population of the Study}

The population of the study comprises of 1,000 students of the women centre for continuing education. This includes women whose education was interrupted because they were withdrawn from conventional schooling to be married out and also women with broken marriages who now consider returning to school as the best way to put their lives back on track.

Fifty (50) stakeholders which comprises of officials from the state ministry of education, teachers of the women centre for continuing education, staff of the state teachers service board, members of a nongovernmental organizations and opinion leaders are also included in the study. 
Factors Responsible For Frequent Withdrawal of Girls from Schools and Their New Enthusiasm ....

\section{Sample and Sampling Techniques}

The survey involved 300 respondents who are students of the women centre for continuing education out of the overall school population of 1000. Three main categories of respondents were randomly chosen for the study. These are married, divorced and unmarried.

For the stakeholders, 30 of the 50 respondents were females, while the remaining 20 were male respondents. Of the 50, a total of 38 (made up of 26 females and 12 males) were civil servants in the service of the Sokoto state government. The remaining 12 respondents (made up of 8 males and 4 females) are from NonGovernmental organizations (NGOs), retired civil servants and self employed people who are both parents, husbands etc.

\section{Instrumentation}

To arrive at fairly reliable conclusion questionnaires were drafted, and developed by the researcher. The first set of questionnaire was distributed to the student respondents at the women centre for continuing education, while the second set were distributed to the stakeholders, made up of officials of the state ministries of education, teachers of women centre for continuing education, staff of the Sokoto state teachers service board, and (NGOs),

\section{Validity of the Research Instruments}

To obtain the validity of the instruments number of items were drafted and taken to the experts in the field of research to vet and determine their suitability for the purpose of the research. From the corrections and suggestions received from the experts, a total of 24 items were selected out of the 30 items on the two questionnaires. At the end, the researcher was able to come up with the final items based on the observations and comments of the experts that were given the instrument to vet.

\section{Reliability of the Research Instrument}

This describes the consistency of the instrument in measuring what it is designed to measure. The method adopted for establishing the reliability of the instrument is the test-re-test method. The 50 copies of questionnaires were administered to 50 students of the women development centre and then responses collected. After two weeks, the same questionnaires were re-administered to the same respondents and the results were compared using Pearson Product Moment Correlation. The reliability index was found to be 0.86 . This was considered reliable.

\section{Data Presentation And Analysis}

The respondents are 300 female students of Women Centre for Continuing Education who mostly dropped out of formal school to get married and later got divorced or widowed. The remaining 50 of the respondents are stakeholders made up of policy makers, civil servants and NGO members. This variable intends to find out how many of them are married, single, divorced and or widowed.

Table 1.1: Marital status of the respondents

\begin{tabular}{|l|l|l|}
\hline Status & Frequency & Percentage \\
\hline Single & 28 & $8 \%$ \\
\hline Married & 42 & $12 \%$ \\
\hline Divorced & 74 & $21.1 \%$ \\
\hline Widowed & 206 & 58.9 \\
\hline Total & $\mathbf{3 5 0}$ & $\mathbf{1 0 0 \%}$ \\
\hline
\end{tabular}

From table 1.1, $12 \%$ of the respondents are married, $8 \%$ single, $21.1 \%$ divorced, and $58.9 \%$ widowed

Research Questions One:

What are the possible reasons for frequent withdrawal of female students from their schools in Sokoto State?

\section{Level of Female Students Withdrawal from School}

The students withdrew from school at various levels from primary to senior secondary school. They were withdrawn to get married to suitors who enticed their parents with so much wealth and relieved the family from financial burden in exchange for their daughters' hands in marriage, and later decided to divorce them and send them to the world of illiteracy.

Table 1.1.2: Showing Level of Students' withdrawal from formal education

\begin{tabular}{|l|l|l|}
\hline Responses & Frequency & Percentage \\
\hline Primary school & 25 & $8.3 \%$ \\
\hline After primary school & 79 & $26.3 \%$ \\
\hline Junior secondary school & 93 & $31 \%$ \\
\hline Senior secondary school & 103 & $34.3 \%$ \\
\hline Total & $\mathbf{3 0 0}$ & $\mathbf{1 0 0 \%}$ \\
\hline
\end{tabular}


The data in table 1.1.2: revealed the years immediately after primary school as the most vulnerable years in terms of withdrawal of the girl child from school. For instance while 25 out of the 300 respondents were withdrawn for marriage while still in primary schools, 275 left schools at various stages between junior secondary school and senior secondary school against their wish. A large figure of 103 respondents were forced to withdraw in senior secondary school merely confirmed the traditional perception that girls within that age group should be playing the role of mothers in their matrimonial homes rather than being spinsters living with their parents.

Table 1.1.3: Showing reasons for students' withdrawal from school

\begin{tabular}{|l|l|l|}
\hline Responses & Frequency & Percentage \\
\hline Marriage & 140 & 47 \\
\hline High cost of education & 140 & 47 \\
\hline Hostile/boring school environment & 20 & 6 \\
\hline Total & $\mathbf{3 0 0}$ & $\mathbf{1 0 0 \%}$ \\
\hline
\end{tabular}

From table 1.1.3 we can see that 140 of the 300 respondents said they forced to marriage before completing their secondary education. The table also brought into light the hidden cost of education which 140 of the respondents claimed was a reason for their withdrawal from school because their parents could not afford their transport fare, uniforms etc.

\section{Research Question Two}

What are the possible reasons for the new enthusiasm on the part of women; single, married, divorcees, widowed for rejoining formal education?

This variable sought to investigate what actually motivated the respondents to go back to school. Table 2.1: Showing Reasons for new enthusiasm of students to rejoin formal education.

\begin{tabular}{|l|l|l|}
\hline Response & Frequency & Percentage \\
\hline Husbands wish & 8 & $2.7 \%$ \\
\hline Self interest & 63 & $21 \%$ \\
\hline To be enlightened & 63 & $21 \%$ \\
\hline To get a good job & 166 & $55.3 \%$ \\
\hline Total & $\mathbf{3 0 0}$ & $\mathbf{1 0 0 \%}$ \\
\hline
\end{tabular}

From table 2.1, it was found that more than half of the respondents rejoined formal education to get good jobs in order to improve their family economy and be self reliant, this is represented by $55.3 \%$ of the respondents, while $2.7 \%$ of the respondents rejoined because their husband wanted them to rejoin. $21 \%$ each said they rejoined to be more enlightened and also saw the need and interest to rejoin the formal school.

\section{Research Question Three}

Could there be different views among single, married, divorcees, and widows for rejoining formal education after years of break?

This variable sought to investigate the possible differences in views amongst single, married, widowed and divorcees for rejoining formal education. Table 3.1, 3.2, 3.3 and 3.4 revealed the various views of the respondents for rejoining formal education system.

Table 3.1: Views of single women respondents

\begin{tabular}{|l|l|l|}
\hline Motivational factor & Frequency & Percentage \\
\hline To be enlightened on govt. programmes and policies & 10 & $41.7 \%$ \\
\hline To get a good job & 14 & $58.3 \%$ \\
\hline Total & $\mathbf{2 4}$ & $\mathbf{1 0 0 \%}$ \\
\hline
\end{tabular}

From table $3.1,41.7 \%$ of the single respondents said they rejoined formal education to be enlightened, while $58.3 \%$ of the respondents said they rejoined to enable them to secure better jobs both at federal and state levels to uplift their standards of living.

Table 3.2: Views of married women respondents

\begin{tabular}{|l|l|l|}
\hline Motivational factor & Frequency & Percentage \\
\hline Husband's wish & 8 & $66.7 \%$ \\
\hline To be enlightened on govt. programmes and policies & 2 & $16.7 \%$ \\
\hline To get a good job & 2 & $16.7 \%$ \\
\hline Total & $\mathbf{1 2}$ & $\mathbf{1 0 0 \%}$ \\
\hline
\end{tabular}

From the table $3.2,8$ out of the 12 married women respondents representing $66.7 \%$ said they rejoined formal educational system because of their husbands' wish of doing so. This is a good development since husbands are now willing to send their wives to school. $16.7 \%$ of the married women respondents said they rejoined formal education to be enlightened and another $16.7 \%$ said they rejoined to get better jobs so that they can take part in sharing their children's responsibilities and not allowing only their husbands to do so. 
Table 3.3: Views of divorced women respondents

\begin{tabular}{|l|l|l|}
\hline Motivational factor & Frequency & Percentage \\
\hline To be enlightened on govt. programmes and policies & 26 & $39.4 \%$ \\
\hline To get a good job & 40 & $60.6 \%$ \\
\hline Total & $\mathbf{6 6}$ & $\mathbf{1 0 0 \%}$ \\
\hline
\end{tabular}

From table $3.3,60.6 \%$ of the divorcees said they rejoined formal education so that they could get good jobs, while $39.4 \%$ said they rejoined formal education in order to be more enlightened so that they would know their rights.

Table 3.4: Views of widowed respondents

\begin{tabular}{|l|l|l|}
\hline Motivational factor & Frequency & Percentage \\
\hline To be enlightened on govt. programmes and policies & 88 & $44.4 \%$ \\
\hline To get a good job & 110 & $55.6 \%$ \\
\hline Total & $\mathbf{1 9 8}$ & $\mathbf{1 0 0 \%}$ \\
\hline
\end{tabular}

From table 3.4, 55.6\% of the widowed respondents said they joined formal education to enable them get good jobs to take care of themselves and their children, while $44.4 \%$ of the widowed respondents joined formal school to enable them to be more enlightened on government programmes and policies.

\section{Summary of the Findings}

For a very long time, the belief has persisted that inadequate enlightment in western education and cultural practices in Sokoto state were the prominent problems facing female education. The two factors have often been cited as being responsible for parents refusal to send their daughters to school or to withdraw their daughters from school for the purpose of giving them out in marriage to some extent, this may be true even though it is no longer tenable to look at the problem solely from this point of view at least going by the findings of this study.

1. Most of the female students in Sokoto State are withdrawn after their primary education and given out for marriage and some withdrew due to high cost of education.

2. The Women Centre for Continuing Education has created a new enthusiasm on the part of women, single, married, divorced and widows, whose dreams were cut short due to one reason or the other. This is to boost their standard of living. These women were encouraged or motivated to go back to school to improve their status. Most of the married women were sent to the school by their husbands who now want their wives to go back to school after the long break. The single, divorced and widowed mostly rejoined formal schooling to get them more enlightened to know more about government programmes and policies, to get themselves better job opportunities which will enable them to improve their family income and take care of their children. They also rejoined to get better suitors to marry at the appropriate time i.e. after secondary education or tertiary education as most of them indicated their plans to go beyond secondary school.

3. Another finding of the research is that there were similar views between divorcees, single and widows in rejoining formal education. These views included to be more enlightened to know the government policies and programmes; to get themselves better jobs so that they could self reliant. But there was a slightly different view when it comes to married women, because majority of them rejoined the formal school as requested by their husbands, because as they said their husbands motivated them to rejoin, very few of them said they rejoined to get a good job or to be enlightened.

\section{Conclusion}

From the data analysis and interpretation of the results, it can be concluded that:

(1) Traditional and cultural practices are some of the impediments in the path of female education. The study further revealed that even though there appears to be growing desire on the part of women to acquire education, there is still a lot to be done especially in traditionally in ward looking societies.

(2) The study further, revealed that much as these girls have high interest in formal education one big problem they have to contend with is the prancing eyes of suitors, most of who are highly placed in society and are charged with promoting female education.

(3) The study also shows that with proper enlightment and co operations from both the parents, husband and society, the gab of educational imbalance between male and female students will be bridged up. This is so because some of the respondents says the rejoined school they have interest, some said because of their husbands' wish, some said because they want to be enlightened on government programmes ad policies and some said because they want to get better jobs to earn their living. 


\section{Recommendations}

The alleged which says if you educate a girl you educate a society is not only true but practically reality. In this regard the following recommendations could be useful:

1. School environment should be made more conducive for learning. This can be done through the promotion of more vocational skills and extra-curricular activities; this will make the students motivated as they can participate in competitions within and outside the school. It is also a step forward if certain incentives could be introduced in the women centre like making education totally free for the students; these could include providing them with free uniforms, stationeries, and transport fares to school. This will take care of any burden which might hinder enrolment into the school by intending students who cannot afford these costs.

2. More efforts should be made to employ more female teachers as they could serve as role models to create enthusiasm on the part of women to come in and get the necessary education that could lead them to professional courses like Doctors, Nurses, Lawyers, etc.

3. Enlightenment campaigns should be stepped up targeting women, parents and husbands as a means of further sensitizing the populace on the importance of education especially for the girl child.

4. The government should also give teeth to its own laws prohibiting the withdrawal of girls from school, and create more job opportunities for women to have a greater enthusiasm to obtain literacy whether they are single, married, divorced or widow as they could always pick up from where they stopped.

\section{References}

[1]. Babuga M.B. et al, (2013), Comparative Analysis of Male and Female Students' Performance in Senior Secondary School Mathematics Promotion Examination in Kebbi State, Nigeria. Unpublished Students Research Project

[2]. Dabo M.I (2000), Problems and Prospects of Girl Child Education in Northern Nigeria: An Islamic Point of View, Journal research of Contemporary Education, 8(4), $314-321$

[3]. Dikko M.D. (2001), Islamic Religion and Women Edcation, Journal Reseach in Education, Vol. 8, page 117-120

[4]. Dukku M.G. (1997), The Problems of Gender Inequality in literacy Participation in Nigeria, Sokoto Educational Review Vol. 4.

[5]. Ibrahim B.A (2008), Challenges on girl Child Education in Nigeria, Unpublished Paper presented at UNICEF Conference in Kano.

[6]. Mahuta M.G. (2001), Some Aspects of Adult Social Education, Reading in Education Vol. 4.

[7]. Muhammad A. and Babuga M. (2004), Factors Militating Against women Choice of Subject Displacing in Tertiary Schools, Which way forward? Journal of Mathematics Association of Nigeria.

[8]. Fafunwa, A.B, (1974) Perspective in African Education Macmillan edition Hongkong. 